\title{
Питання психології
}

УДК 323.232:659]:159.9](477)

DOI: $10.33099 / 2617-6858-20-58-5-41-47$

Віннічук О. В. кандидат політичних наук, доиент кафедри політології та філософії

Кам'янеиь-Подільського начіонального

університету імені Івана Огієнка

https://orcid.org/0000-0002-8758-5798

Білещька Т.В. кандидат сочіологічних наук, доцент кафедри психології, педагогіки та сочіально-

економічних дисииплін Національної академії Держсавної

прикордонної служби України імені Богдана Хмельницького

https://orcid.org/0000-0002-8844-5842

\section{ПСИХОЛОГІЧНІ АСПЕКТИ В ПОЛІТИЧНІЙ РЕКЛАМІ: УКРАЇНСЬКИЙ ДОСВІД}

У статті презентовано аналіз психологічної складової в політичній рекламі з врахуванням українських реалій та практик. Визначено, щзо політична реклама в умовах глобалізованого інформачійного суспільства виступає засобом активного психологічного впливу на людську психіку, стимулюючи ї̈ емоиії, регулюючи поведінку, спрямовуючи політичну свідомість. Автори простежсили особливості технологій, які найчастіше використовуються в сфері вітчизняної політичної реклами.

Ключові слова: реклама; політична реклама; психологія політичної реклами; масова свідомість; маніпулятивні технологіi.

Вступ. Зміни, що відбулися у розвитку українського суспільства в останні десятиліття та супроводжувалися суттєвими соціально-політичними перетвореннями, розпадом попередніх структур влади, переосмисленням та трансформацією суспільних цінностей та ідеалів, детермінували увагу науковців на вивчення інститутів, що впливають на масову свідомість. Серед них ключова роль належить комунікаційним структурам та механізмам передачі інформації. Остання залишається базисом соціальної взаємодії, визначає іiі характер, особливості, а також створює можливості для впливу на масову свідомість $i$ поведінку. Сферою, в межах якої, найчастіше використовуються маніпулятивні практики $\epsilon$ інститут політичної реклами. Його основні завдання полягають у стимулюванні уваги та інтересів суспільства до політичних подій, перипетій, формуванні мотивованих уподобань громадян, їх політичної та електоральної активності. 3 метою реалізації такого впливу використовуються різні інструменти та методи, спектр яких постійно розширюється та удосконалюється. Простежимо найбільш розповсюджені вітчизняні практики політичної реклами.
Метою роботи $\epsilon$ аналіз психологічної складової в політичній рекламі з врахуванням української практики.

Теоретичне підгрунтя. Теоретичні аспекти психологічного впливу на масове суспільство, згодом публіку, свого часу аналізувалися у роботах таких вчених, як Г. Лебона, 3. Фрейда, К. Юнга, Д. Тарда С. КараМурза, С. Московичі. Окремі аспекти дослідження маніпулятивної складової в політичній рекламі знайшли відображення у наукових працях українських дослідників Г. Почепцова, В. Іванова, Н. Вітюка, М. Вівчарика, О. Зернецької.

Результати і обговорення. В умовах сьогодення реклама виступає невід'ємним атрибутом нашого повсякденного життя. Вона присутня в політичній, економічній, духовній, соціальній сферах життя суспільства. Вдала та вчасна реклама $\epsilon$ запорукою успішної реалізації будь якого проекту. Адже саме вона впливає на установки, стереотипи населення, формує їх цінності.

У законі України "Про рекламу" пропонується наступне визначення реклами: "реклама - це спеціальна інформація про осіб чи продукцію, яка розповсюджується в будь- 


\section{Питання психології}

якій формі і в будь-який спосіб 3 метою прямого або опосередкованого одержання зиску" [4].

Перші дослідження реклами як явища у межах психологічної складової відносяться до кінця XIX - початку XX століття. У США основоположником психології реклами визнано У. Дж. Скотта, який запропонував світу роботу "Теорія і практика реклами" на початку XX ст., а згодом - книгу "Психологія реклами".

Вперше рекламу у виборчий процес було впроваджено федералістами США у 1798 р., прийнявши "Акт про відповідальність за антиурядову агітацію”. Створення професійних груп, які спеціалізувалися безпосередньо у сфері політичної реклами, відбувалось у 1934 р., коли в Каліфорнії Вайтекер i Бакстер заснували фірму, яка забезпечувала рекламну підтримку республіканцям.

Відомий американський фахівець 3 реклами Дж. Луїс одного разу зауважив: "Добре це чи погано, але факт, що реклама єдиний спосіб, за допомогою якого кандидат може розказати про свої чесноти. Без реклами будь-який кандидат, незважаючи на усі свої благородні якості, буде просто знищений, на нього просто ніхто не зверне уваги" $[8,49]$.

Політична реклама виступає засобом активного психологічного впливу на людську психіку, стимулюючи іiі емоції, регулюючи поведінку, спрямовуючи політичну свідомість.

На думку відомих дослідників Г. Васильєва та В. Полякова, політична реклама - це грамотне, коректне і цілеспрямоване виявлення, підкреслення i демонстрація різним соціальним і національним групам виборців саме тих якостей та достоїнств претендентів на лідерство, до яких ці групи виявляють особливий інтерес. Вона $\epsilon$ важливим джерелом комунікації, за допомогою якої політики та їхні команди збільшують ефективність своїх кампаній під час виборів і підтримують імідж своїх партій між виборчими кампаніями $[1,23]$.

Вартий уваги раціональний підхід поведінки виборця, в межах якого індивід керується раціонально проаналізованою політичною ситуацією, власними інтересами, незважаючи на установки та вплив об'єктивних факторів. Такий виборець зазвичай віддає перевагу тому кандидату, який продемонструє свою дієвість [10].

Проте теорія раціонального вибору, яка намагалася перетворити виборця на свідомого суб'єкта не отримала належної підтримки серед наукових кіл через перебільшення рівня «раціональності» у поведінці виборця.

Заперечуючи раціональний підхід поведінки виборця, відомі американські дослідники С. Розенберг і П. Маккаферті запропонували теорію “ірраціонального вибору”. Дослідники намагалися довести факт рівня значущості політичних виборів. Наприклад, явка громадян на вибори президента зазвичай виявляється вищою, ніж під час виборів до місцевих органів влади. Крім того, дослідники зауважили, що через упевненість у перемозі партії, яка вже раніше вигравала виборчі перегони, у виборців зникає відчуття необхідності й важливості для результату виборів власного голосу, в результаті якої відбувається електоральна демобілізація $[12,109]$.

Таким чином, варто зазначити, що від здатності оцінювати інформацію, виявляти власну політичну позицію залежить безпосередньо активна/пасивна, раціональна/ірраціональна поведінка виборця, його мотивація до зацікавленості та впливу на електоральний процес, а відповідно спроможність регламентувати політичне життя суспільства.

Беззаперечно, що одним 3 важливих аспектів політичної реклами $є$ саме мотивація поведінки громадян шляхом прихованого впливу. Зокрема, участь ЗМІ у формуванні громадської думки дозволяе політикам активізовувати чи пригнічувати свідомість громадян, шляхом застосування сучасних маніпулятивних технологій (маніпулювання, НЛП, НПП тощо).

Таким чином, на особливу увагу заслуговує маніпулятивний підхід до аналізу електоральної поведінки, який грунтується на уявленні про залежність ідейно-політичних позицій виборців від впливу на них ЗМІ та інститутів влади. 


\section{Питання психології}

В середині XX ст. в результаті проведених досліджень відомий американський дослідник П. Лазарсфельд зазначив, що на результати голосування індивіда суттєво впливають: релігійна приналежність, соціальний клас, сім'я, стосунки на робочому місці, місцеві групи тиску, масові засоби комунікації, соціальноекономічний статус та інші чинники [11].

Серед тенденцій взаємодії влади та суспільства в умовах сьогодення спостерігається поступовий відхід від авторитаризму й цензури до інноваційних методів маніпулювання, 3 метою контролю громадської думки.

Зокрема, на особливу увагу заслуговують наступні техніки психологічного впливу: фрагментація інформації i кліпмейкерство (коли 3 інтерв'ю людини вирізаються фрагменти, відсутність яких викривляє суть сказаного), «просочування» секретної службової інформації (організовується 3 метою «скидання» компромату журналістам), семантичне маніпулювання (ретельний відбір слів, термінів, понять, що викликають або позитивні, або негативні асоціації. Це дозволяє створити образ месії чи, навпаки, ворога), “закидання багнюкою” (система таких визначень і метафор у журналістському тексті, які надають об'єкту вкрай негативну окраску), історичні аналогії (некоректні порівняння й асоціації, чутки, легенди), “копчений оселедець” (подача в сенсаційній формі певного повідомлення для відвернення уваги аудиторії від іншої інформації - за змістом важливішої, але незручної для влади), псевдоподія (інсценування події), “випадкова вибірка" (свідчення пересічних громадян та експертів наводяться на основі "випадкової вибірки” висловів, системи питань, що містять у собі потрібні відповіді для підтвердження позицій журналіста), дезінформація (цитування журналістами неправдивої інформації) та ін. [5].

Відомий дослідник 3. Партико виділяє методи передпропаганди та безпосередньо пропаганди. Серед методів передпропаганди варто відзначити: "пробні кулі", “створення загрози”, “сенсаційність і терміновість”, "перевантаження повідомленнями" та “емоційний резонанс" [7].

Методів маніпулятивного впливу та пропаганди можна наводити безліч, проте найвідомішими 3 них $\epsilon$ посилання на авторитет та буденна розповідь, коли журналісти посилаються на відомих людей, висловлюючи потрібну інформацію, або взагалі розповідають про подію як про щось звичне.

Доволі популярним методом в українському соціумі $\epsilon$ технологія “тримайте злодія". Його використовують за умови, коли суб'єкту політики було прищеплено негативний імідж. Наприклад, в країнах, де корупційні, олігархічні клани отримали більшість у парламенті, вони спершу починають “твердо боротися" з мафією (тобто 3 самими собою), а далі, не бажаючи “впіймати” самих себе, звинувачують у корупції та інших злочинах парламентську опозицію [5].

У 2017 році Представники ОБСЕ 3 питань свободи ЗМІ разом зі Спеціальними доповідачами $\mathrm{OOH}$ прийняли спільну декларацію про свободу вираження думки, а також “фейкові” новини, дезінформацію та пропаганду. У цьому документі вони звернули особливу увагу на широке розповсюдження в традиційних 3MI i соціальних мережах дезінформації та пропаганди, за якими стоять як державні, так і недержавні суб'єкти, а також наголосили на різних негативних явищах, які можуть виникати під впливом такої практики.

Вони висловили занепокоєння $з$ приводу того, що дезінформація та пропаганда часто покликані вводити людей в оману, а також перешкоджати реалізації права суспільства знати і прав громадян шукати і отримувати, а також поширювати, незалежно від державних кордонів, різного роду інформацію та ідеї, тобто прав, які захищені міжнародноправовими гарантіями прав на свободу переконань і вираження поглядів [6, 13].

Виборча президентська та парламентська кампанія в Україні 2019 році засвідчила суцільну маніпуляцію на темі “нові обличчя", зауважує незалежний медіаексперт Win Win Communication Л. Мудрак. 


\section{Питання психології}

Експерт наголошує на наступних маніпулятивних технологіях, які мали місце під час виборчої кампанії:

політична компетентність нових людей (менеджерський досвід - це не політична компетентність);

заклики до руйнування старої політичної системи, за умови відсутності у програмах ключових аспектів, окрім популізму (мета - отримати підтримку електорату);

презентації партій - це лише яскраві обгортки, а не суть нового продукту, адже про ідеологію чи стратегію змін ніхто не говорить; “просуваємо яскраве" - концерти, шоу, виступи - це намагання емоційно підкупити електорат, а не апелювання до розуму виборців [9].

Зазначені аспекти вказують на використання традиційних застарілих підходів до ведення виборчої кампанії, незважаючи на запити суспільства на оновлені техніки ведення передвиборчих гонок.

Аналізуючи виборчу активність політичних партій, кандидатів у президенти та кандидатів-мажоритарників, варто зауважити, що основними темами для обговорення на виборчих платформах стали: актуальність війни та миру; високого соціальноекономічного рівня життя; векторів розвитку країни; релігії; мови; становища національних меншин тощо.

Також, абсолютно новим трендом останньої виборчої кампанії в Україні було намагання політичних сил представити електорату нові обличчя, які ще не мали причетності до сфери політики.

Аналізуючи офіційну та неофіційну політичну рекламу кандидатів у президенти 2019 р. П. О. Порошенка В. О. Зеленського під час виборчої кампанії експерти організації Democracy Reporting International відзначили:

- на офіційних сторінках кампанії не використовувались маніпулятивні стратегії для дискредитації опонентів та тон критики був помірним;

- кампанія В. О. Зеленського частіше використовувала технологію мікротаргетингу та більш активно залучала виборців, тоді як інформаційні блоки на сайті П. О. Порошенка був менш привабливим, хоча витрати на поширення кожного поста були більшими;

- неофіційні сторінки кампаній обох кандидатів намагались очорнити конкурента. Витрати на сторінки, спрямовані проти В. О. Зеленського, значно перевищували витрати на сторінки проти П. О. Порошенка;

- між неофіційними сторінками та офіційними штабами двох кандидатів були виявлені прямі й опосередковані зв'язки;

- іноді рекламні оголошення 3 позначкою "Не відповідає правилам рекламної діяльності на Facebook" видалялись Facebook iз затримкою, а витрати на момент видалення перевищували 1000 доларів [3].

Необхідно зазначити, що офіційні сторінки передвиборчої кампанії обох кандидатів не використовували маніпулятивні стратегії з метою дискредитації конкурентів на виборах.

Зокрема, на сторінці екс-президента П. Порошенка розміщувалася формальна політична реклама, яка зосереджувалася на позитивній агітації та нагадуванні виборцям про свої президентські досягнення: розвиток армії, надання Томосу для створення незалежної Української Православної Церкви, успіхи в популяризації української мови, стратегія подолання бідності в країні, висвітлювалася позиція щодо підтримки проєвропейської позиції Україною.

Що стосується офіційного сайту президента В. О. Зеленського, то 3 метою проведення успішної виборчої кампанії його командою було обрано більш розважальну стратегію (3 урахуванням його репутації комедійного актора). Також спостерігалися елементи прихованої маніпулятивної тактики стосовно електорату. Яскравим прикладом можуть слугувати заклики щодо прояву власної позиції та політичної активності не просто прийнявши участь у голосування, а й стати спостерігачами або членами виборчих комісій, фіксувати випадки порушень на дільницях та надсилати їх до виборчого штабу. Особливу роль зіграв меседж про те, що "нинішня влада зробить все, щоб перемогти нечесним шляхом”. 


\section{Питання психології}

Таким чином, варто зазначити, що найбільш сумнівним та водночас успішним контентом $\epsilon$ той, що заграє з емоціями людей, а також контент, який найчастіше схвалюють та поширюють, навіть не прочитавши та не зрозумівши його.

\section{Висновки та перспективи подалыших досліджень.}

Отже, важливе значення для представників сучасного електорату має ряд соціально-психологічних чинників: політичні установки, цінності, стереотипи, які виступають фундаментальними складовими успішного процесу політичної соціалізації. Ці аспекти, власне кажучи, і вказують на рівень політичної відповідальності громадян.

Прийняття зваженого та компетентного рішення виборця залежить великою мірою від належної поінформованості з різних джерел (зовнішня реклама, сувенірна реклама, 3МІ, інтернет-джерела тощо) про особистості суб'єктів політичного процесу, їх передвиборчі програми, рівня електоральної активності, політичної свідомості громадян, психологічної готовності до прийняття політично виваженого рішення.

$\begin{array}{lrrr}\text { Подальшi } & \text { дослідження } & \text { в } & \text { межах } \\ \text { зазначеної } & \text { проблематики } & \text { доцільно }\end{array}$
спрямовувати в напрямку дослідження тенденцій маніпулятивного впливу політичної реклами на український електорат, а також шляхів законодавчого обмеження у застосуванні прихованого психологічного впливу.

\section{Список використаних джерел}

1. Бутенко Н. В. Основи маркетингу: підручник. Київ: Атіка, 2008. 195 с.

2. Вітюк Н. Соціально-психологічні особливості електорального вибору // Вісник Прикарпатського університету. Філософські і психологічні науки. 2019. Вип. 22. С. 59-67. URL: http://nbuv.gov.ua/UJRN/Vpu_filos_psihol_2019_22_11.

3. Дволика передвиборча кампанія. Президенські вибори в Україні 2019. URL: https://democracyreporting.org/ua/social-media-ukraine-elections/

4. Закон України Про рекламу від 03.07.1996 № 270/96-ВР.

5. Олексієнко Н. Особливості політичної реклами. URL: https://jyrnalist.com.ua/osoblivostipolitichnoyi-reklami/

6. Кужель Р., Бурмагін О. Президентські і парламентські вибори 2019. Україна. Методологія моніторингу 3МI. 2019. $81 \mathrm{c}$.

7. Почепцов Г. Г. Имидж и выборы: имидж политики, партии, президента. Київ : АДЕФ Украина, 1997. $140 \mathrm{c}$.

8. Феофанов О. Реклама: новые технологии в России. СПб.: Питер, 2000. 384 с.

9. Шоргін І. Маніпуляції та прорахунки виборчої кампанії. Що не так із політичною рекламою? ПОЛІТИКА. 2019. 7 Липня. URL: https://www.radiosvoboda.org/a/30035638.html
10. Downs
A. An
Economic
Theory
Democracy.
URL: http://polisci2.ucsd.edu/foundation/documents/06Downs1957.pdf.

11. Lazarsfeld P. F., Berelson B., Gaudet H. The People's Choice : How the Voter Makes up His Mind in a Presidential Campaign. URL : peopleschoice\%20.pdf.

12. Rosenberg S. W., Bohan L., McCafferty P., Harris K. The Image and the Vote: The Effect Of Candidate Representation on the Voter Preference. American Journal of Political Science. 1986. Vol. 30. P. 108127.

\section{References}

1. Butenko N. V. Osnovi marketingu: pidruchnik. Kiïv: Atika, 2008. $195 \mathrm{~s}$ (in Ukrainian).

2. Vityuk N. Sotsialno-psikhologichni osoblivosti elektoralnogo viboru // Visnik Prikarpatskogo universitetu. Filosofski i psikhologichni nauki. 2019. Vip. 22. S. 59-67. URL: http://nbuv.gov.ua/UJRN/Vpu_filos_psihol_2019_22_11 (in Ukrainian).

3. Dvolika peredviborcha kampaniya. Prezidenski vibori v Ukraïni 2019. URL: https://democracyreporting.org/ua/social-media-ukraine-elections/ (in Ukrainian).

4. Zakon Ukraïni Pro reklamu vid 03.07.1996 № 270/96-VR (in Ukrainian). 


\title{
Питання психології
}

5. Oleksienko N. Osoblivosti politichnoï reklami. URL: https://jyrnalist.com.ua/osoblivosti-politichnoyireklami/ (in Ukrainian).

6. Kuzhel R., Burmagin O. Prezidentski i parlamentski vibori 2019. Ukräna. Metodologiya monitoringu ZMI. 2019. $81 \mathrm{~s}$ (in Ukrainian).

7. Pocheptsov G. G. Imidzh i vybory: imidzh politiki, partii, prezidenta. Kiïv : ADYeF - Ukraina, 1997. $140 \mathrm{~s}$ (in Ukrainian).

8. Feofanov O. Reklama: novye tekhnologii v Rossii. SPb.: Piter, 2000. 384 s (in Russian).

9. Shorgin I. Manipulyatsiï ta prorakhunki viborchoï kampaniï. Shcho ne tak iz politichnoyu reklamoyu? POLITIKA. 2019. 7 Lipnya. URL: https://www.radiosvoboda.org/a/30035638.html (in Ukrainian).
10. Downs
A.
An
Economic
Theory
of
Democracy.
URL:

http://polisci2.ucsd.edu/foundation/documents/06Downs1957.pdf.

11. Lazarsfeld P. F., Berelson B., Gaudet H. The People's Choice : How the Voter Makes up His Mind in a Presidential Campaign. URL : peopleschoice\%20.pdf.

12. Rosenberg S. W., Bohan L., McCafferty P., Harris K. The Image and the Vote: The Effect Of Candidate Representation on the Voter Preference. American Journal of Political Science. 1986. Vol. 30. P. 108-127.

\section{Резюме \\ Винничук О. кандидат политических наук, доцент кафедры политологии и философии Каменеи-Подольского начионального университета имени Ивана Огиенко \\ Билецкая Т. кандидат сои. наук, доиент кафедры психологии, педагогики и сочиально-экономических дисииплин Наииональной академии Государственной пограничной службы Украины имени Богдана Хмельниикого \\ ПСИХОЛОГИЧЕСКИЕ АСПЕКТЫ В ПОЛИТИЧЕСКОЙ РЕКЛАМЕ: УКРАИНСКИЙ ОПЫТ}

В статье представлен анализ психологической составляющей в политической рекламе с учетом украинских реалий и практик. Определено, что политическая реклама в условиях глобализируюшегося информационного общества выступает средством активного психологического воздействия на человеческую психику, стимулируя ее эмоции, регулируя поведение, направляя политическое сознание. Авторы проследили особенности технологий, которые чаще всего используются в сфере отечественной политической рекламы.

Ключевые слова: реклама; политическая реклама; психология политической рекламы; массовое сознание; манипулятивные технологии.

\author{
Summary \\ Vinnichuk $\boldsymbol{O}$. Candidate of Political Science, \\ Associate Professor of the Department of Political \\ Science and Philosophy Kamyanets-Podilskyi \\ National University named after Ivan Ohienko \\ Biletskaya T. candidate social. Sciences, Associate \\ Professor of the Department psychology, pedagogy and \\ socio-economic disciplines National Academy of the State \\ Border Service of Ukraine named after Bohdan Khmelnitsky
}

PSYCHOLOGICAL ASPECTS IN POLITICAL ADVERTISING: UKRAINIAN EXPERIENCE

Introduction Changes which happened during development of the Ukrainian society in past decades and accompanied by significant socio-political transformations, previous power structures break up rethinking and transformation of the system of social values and ideals, has determined an attention of scientists on researching the institutes which make influence on the mass consciousness. Among them key role belongs to communicative structures and mechanisms of information transfer. The area within which manipulative practices are most often used is the institution of political advertising. Its main tasks are to stimulate public attention and interests in political events, vicissitudes, formation of motivated preferences of citizens, their political and electoral activity. In order to realize such influence, various tools and methods are used, the spectrum of which is constantly expanding and improving. We will trace the most common domestic practices of political advertising. 


\section{Питання психології}

Purpose The purpose of the work is to analyze the psychological component in political advertising, taking into account Ukrainian practice.

Methods: During the study, the following methods were used: analytical, on the basis of which a number of signs of political advertising were highlighted, the psychological peculiarities of its impact on mass consciousness and behavior were investigated. The authors also used a systematic method by which political advertising is considered as a complex process, the most important elements of it are identified, their interdependence and mutual predetermine are traced;

\section{Originality}

The 2019 presidential and parliamentary campaign in Ukraine showed continuous manipulation on the topic of "new faces", besides the following manipulative technologies were also used:

-political competence of new people (managerial experience is not political competence);

- calls for the destruction of the old political system, in the absence of key aspects in the programs, in addition to populism (the goal is to get the support of the electorate);

-party presentations are only bright wrappers, not the essence of a new product, because nobody talks about ideology or strategy of change;

-"promoting bright" - concerts, shows, performances - is an attempt to emotionally bribe the electorate, not appealing to the minds of voters.

These aspects point to the use of traditional outdated approaches to the conduct of the election campaign, despite the society's requests for updated techniques for running election races.

Conclusion The adoption of a balanced and competent decision of the voter depends largely on proper awareness from different sources (outdoor advertising, souvenir advertising, media, internet sources, etc.) about the personalities of subjects of the political process, their election programs, the level of electoral activity, political consciousness of citizens, psychological readiness to make a politically balanced decision.

Further research within this problem is advisable to direct in the direction of researching trends of manipulative influence of political advertising on the Ukrainian electorate, as well as ways of legislative restriction in the use of hidden psychological influence

Key words: advertising; political advertising; psychology of political advertising; mass consciousness; manipulative technologies.

Автори заявляють об відсугності конфлікту інтересів.

Recelved/Поступила: 25.1220. 